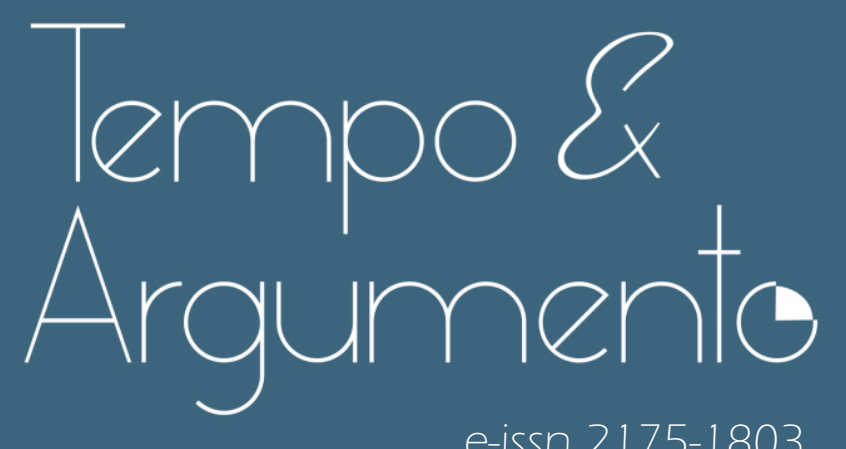

e-issn 2175-1803

\title{
Vocational education memories: meanings and sensibilities in the early religious life at the Congregation of the Sisters Servants of the Immaculate Conception (1960-1990)
}

- Caroline Jaques Cubas

Professor at the Department of History and the Graduate Program in History, area of concentration History of the Present Time, in the Center for Human Sciences and Education of the Santa Catarina State University (UDESC).

Florianópolis, SC - BRAZIL

lattes.cnpq.br/8047265228290870

caroljcubas@gmail.com

(i) orcid.org/0000-0001-5411-6824

Translation of the article "Memórias de formação: sentidos e sensibilidades durante o início da vida religiosa na Congregação das Irmãzinhas da Imaculada Conceição (1960-1990)" published in the Journal Tempo e Argumento, Florianópolis, v. 2, n. 2, p. 44 - 60, jul./dez. 2010.

http://dx.doi.org/10.5965/2175180302022010044

Translator: Evandro L. Freire

Received on: April 2010

Approved on: May 2010 
Vocational education memories: meanings and sensibilities in the early religious life at the Congregation of the Sisters Servants of the Immaculate Conception (1960-1990)

\begin{abstract}
This article aims to discuss various aspects of female religious vocational education from the perspective of sensibility and discipline. To do this, we bring testimonies of women who underwent the vocational education process at the Congregation of the Sisters Servants of the Immaculate Conception. The utterances, in dialogue with professional education handbooks, build a rather large panorama, which makes it possible to glimpse the construction of meanings and vocations for later work institutionally linked to the Catholic Church.
\end{abstract}

Keywords: Religious life. Vocational education. Discipline. Memory.

Memórias de formação: sentidos e sensibilidades durante o início da vida religiosa na Congregação das Irmãzinhas da Imaculada Conceição (1960-1990)

\begin{abstract}
Resumo
O objetivo deste artigo é discutir diferentes aspectos da formação religiosa feminina sob a ótica da sensibilidade e do disciplinamento. Para tanto, apresentamos testemunhos de mulheres que passaram pelo processo de formação na Congregação das Irmãzinhas da Imaculada Conceição. Os depoimentos, postos em diálogo com os manuais de formação, constroem um panorama bastante amplo, o qual possibilita vislumbrar a construção de sentidos e de vocações para o posterior trabalho institucionalmente ligado à Igreja Católica.
\end{abstract}

Palavras-chave: Vida religiosa. Formação. Disciplina. Memória. 
My memories take me to that house... Blue with an area full of ferns, a laundry sink, a shining floor, a black and white TV, a red sofa... I draw everything when I recall it

Onice easily recalls, in color, her vocational education years at the the Sisters Servants of the Immaculate Conception's houses, in the late 1980s. As she recalls, a strong sense of belonging emerged since, during the vocational education years, people got in touch with their deepest feelings. When talking about the sisters servants, she agrees to report in detail on the house where she lived, everything she did, everything she learned, how things smelled ${ }^{2}$. What marked and still remains in her body. The habits experienced and embodied. Indeed, she conveyed emotional and sentimental feelings to remember her congregation years. Even today, she claims the impossibility of going unpunished through Colégio São José or through the municipality of Nova Trento (the way how she referred to congregation in the State of Santa Catarina, Brazil) ${ }^{3}$.

Religious vocational education took place (and this still remains the same) in stages: vocational awakening, aspirant group, postulant group, novitiate, juniorate, and ongoing vocational education. Such steps had some specificities and they were not static. They were held in various spaces, known as Vocational Education Houses, and typified an intense learning period. It took, on average, four years, over which the prospective young sister servant effectively learned to be a religious woman, i.e. to live and feel this way.

Each of the stages mentioned above took place in a specific house. According to Sister Maria Cristofolini, roaming has a symbolic meaning. "Sisters cannot take root," she told us, when explaining that each vocational education stage, as well as religious life itself, takes place in an itinerant way, because they follow Christ and Mother Pauline's life goal. Such a goal, whose main purpose is

\footnotetext{
'SANSONOWICZ, Onice. [Correspondence]. Addressee: Irmã Eni. 2005. 1 personal letter.

2 SANSONOWICZ, Onice. [Interviewed by Caroline Jaques Cubas. Mar 26th. 2006. Author's collection.

${ }^{3}$ SANSONOWICZ, Onice. [Interviewed by Caroline Jaques Cubas. Mar 26th. 2006. Author's collection.
} 
the search for holiness, implies spreading the gospel and being available to meet the other's needs ${ }^{4}$.

The issue of vocational education gains momentum when we take into account that priestly work provides Church's power with its symbolic support base. This is due to the fact that priestly work embodies the legitimacy of manipulating goods and the monopoly of religious discourse. The priestly team embodies the Catholic identity through consecration acts and rites that establish it as an authorized representative of the institution, enabling its members to be acknowledged as playing that role.

The space for priestly work (i.e. sisters' work) goes beyond political boundaries. It is shaped by the relations established between religious women and lay people. Vocational education takes place in the very conformation of these symbolic spaces, in a two-way process, where the sisters devote themselves to the work of spreading the religious truth through the congregation and lay people legitimize and enable their task by regarding these religious women as representatives of an institution, thus providing them with the power to do so.

The maximum number of women seeking vocational education at the house varied according to each community's size and circumstances. It is worth remembering that they depended on sisters' work itself, therefore, in most cases, they engaged in works parallel to those related to house maintenance. However, a very large number of women seeking vocational education in each house was not informed, they usually varied between 2 and 6 per community. It was during the training period that, by means of classes, as well as by dividing tasks and distributing duties, a prospective sister could be shaped as she adopted a disciplined behavior pattern. According to Foucault (1998, p. 126), "these methods that allow a detailed control of body's operations, which constantly subjugate its forces and impose a docility-utility relationship on them, are what we may name as 'disciplines'." The word discipline, in fact, is the caption referring to the usefulness of the silicon that had belonged to Mother Paulina, currently on 
display at the Congregation's Museum, in São Paulo, Brazil. Silicon, a belt with small nails, used at thigh height, was a disciplinary instrument for restraining desires via bodily sacrifice. It began to fall into disuse from the 1960s on, after the Second Vatican Council. Although the mortifying methods were no longer so recurrent to enforce discipline, the latter never ceased to be observed, characterizing one of the main components of vocational education and religious life. Thus, the training structure is arranged in a very disciplinary way, in order to 'produce' docile bodies, submissive to authority.

The division of vocational education's spaces in various houses according to the training stage proves this assertion. At each stage, a woman seeking vocational education came into contact with (bodily and spiritual) exercises specific to the level which she was at and, thus, gradually acquired skills for religious life. According to Foucault (1998, p. 187):

The theme of perfection, towards which a role model master leads, becomes among them an issue of authoritarian students' improvement triggered by the teacher; the increasingly rigorous exercises proposed by ascetic life become increasingly complex tasks that mark a progressive acquisition of knowledge and good behavior pattern.

The training time showed to be a specialized time, during which a woman seeking vocational education was analyzed and ranked according to the requirements established during the various phases. The division into stages also enabled greater control and timely intervention in relation to each specific moment. Onice reports that, despite the careful control, the likelihood of deceiving it was quite high in the daily life of the houses: "we woke up early, and we hated that; so we locked the alarm clock... sometimes. We missed the time for praying... oh, what a shame! [in an ironic tone] And everyone headed to work sad, without praying..." As time is one of the key elements of disciplinary control, locking the clock acquired a unique meaning, i.e. clashing with discipline and, also, verticalizing power relations that were introduced to women seeking vocational education in a hierarchical manner.

5 SANSONOWICZ, 2006, op. cit. 
Human skin is parchment. According to Michel de Certeau (1994), bodies are marked on a daily basis and turned into living pictures that depict rules and customs. In the case of religious life, it is especially during the training period that such rules are inscribed on the human body. Thus, the congregation's constitutions end up defining the statute of what should be taught and learned by prospective sisters.

The need for a standard aimed at regulating common life emerged in the early decades of the congregation, in the late $19^{\text {th }}$ century, when the Jesuit priest Marcello Rocchi proposed a kind of rule to Amábile (M. Paulina) and Virgínia (M. Matilde), consisting of 38 spiritual exercises that alternate between methods providing insights on the spirit, conscientiousness, and feeling within the church 6 . Altogether, the congregation had 5 versions of its constitutions and guidelines; the latest update, issued shortly after the Second Vatican Council, was introduced to the congregation for religious people and secular institutes in 1978 and, finally, approved by decree in 1982. The sisters who experienced religious vocational education within the period from 1960 to 1990 were ruled by what is proposed in this version.

According to Sister Leodi, training was uniquely customized. It was up to a woman seeking vocational education and the master to decide when she should remain at a stage or move on? ${ }^{7}$ Sister Leodi's claim gains momentum when we read, in the congregation's guidelines, the general objective of religious vocational education: "to provide conditions to find out and adopt God's design for oneself". This God's design, i.e. the work to be undertaken by a sister after the vows, was closely linked to the congregation's needs. Making individual will submissive to institutional needs is just one of the circumstances captured throughout the process and assumed along with religious vows. There is, however, a lengthy and complex path that precedes this ritual, which begins with discovering one's vocation.

\footnotetext{
${ }^{6}$ Cf. CONGREGAÇÃO PARA A CAUSA DOS SANTOS. Madre Paulina: fundadora da Congregação das Irmãzinhas da Imaculada Conceição - biografia comentada. São Paulo: [s. n.], 1986.

BOLZAN, Leodi. [Entrevista cedida a] Caroline Jaques Cubas. Itajaí, set. 2004. Acervo da autora.

${ }^{8}$ CONGREGAÇÃO DAS IRMÃZINHAS DA IMACULADA CONCEIÇÃO - CIIC. Diretório. São Paulo: CIIC, [1982], p. 63.
} 
Vocation, within a religious congregation, is a calling. A willingness that drives the exercise of an activity. However, there is a need to push such a willingness and this is due to the well-known vocational willingness, a stage that precedes vocational education.

All sisters are potential players in terms of vocational willingness; but some of them are specifically assigned to work in this area, with direct support of the person in charge of training in each province. In addition to the players who work directly along with the applicants, in each region, people are encouraged by parish priests and there is the press media.

Sister Maria Cristofollini, born in Rodeio, Santa Catarina, Brazil - and member of the Congregation of the Sisters Servants of the Immaculate Conception for more than 50 years -, says that she knew the congregation in meetings with other young women, held by the local parish priest, who introduced the peculiarities of each congregation and the possibilities of joining them. She came from a very Catholic family, just like Sister Leodi Bolzan. The latter, when describing how she met the Sisters Servants of the Immaculate Conception, reports:

I didn't think much about the university entrance exam, I already thought about a course that could provide me with a job that had an affinity with me [...]. Through sisters' work at the vocational clubs in the community where I lived, I awoke to this vocation type. I attended vocational clubs and stayed at the Sisters' houses countless times, I lived for a year with the Sisters near my father's house to see what it was like [...]. They worked at the hospital, so I often helped them to learn the kind of work that the sisters do, too, and helped with catechesis, liturgy, participated in youth groups, I was already engaging in this along with the sisters. At that time, I was 15 years old and there was a growing vocation?.

Vocation to religious life was much more than awakened. It was taught through meetings and intensive monitoring along with those who showed some propensity for the work done by the sisters. Mirian P. Grossi (1990) makes a similar observation in a study on female religious life in convents located in Santa Catarina, Brazil, when she claims that female celibacy is a choice made by the 
Church itself as an institution, in an attempt to reproduce materially and symbolically. She emphasizes the intense catechetical work carried out by priests and nuns, especially in rural areas, where they establish bonds and affective relationships. Both Sister Maria and Sister Leodi confirm this assertion. This leads us to think, also according to Grossi (1990), of vocations as a result of material and symbolic needs, both on an individual and a collective basis.

Sister Eni da Silva, as a teenager, dreamed of having children. She enjoyed working at the church, participating in a youth group, and, someday, prompted by a friend and an ad in the parish church's newspaper, she ended up writing to the congregation in order to get to know it. She exchanged letters with the sisters for a few months, but the difficulties imposed by her family (financial constraints and disagreement regarding the possibility of joining a congregation) appease her will, resumed years later, when she and her sister left home to study and work in a location different from the rural area where they used to live. The congregation, according to Eni, represented the fulfillment of dreams, among which studying, social work and, later, knowing the African continent, where she worked for some years as a missionary ${ }^{10}$.

Family's disagreement with Eni's choice may be interpreted in a tense scenario. Tension between symbolic fields. The entry of a daughter into a religious congregation might be a loss in terms of social capital, as she could not marry, therefore, she would become unable to perpetuate her lineage and her family. On the other hand, having a nun daughter represented an increase in the family's symbolic capital. Especially in rural communities, a priest son or a nun daughter was an element of prestige, indeed.

Onice Sansonowicz also faced difficulties in joining the congregation. Institutional difficulties. She also had an affinity with parish work, especially with catechesis and youth pastoral work. Her family was fervently Catholic and saw the priest as a close friend. Father Osvaldo, quite devoted to the entry work and 'a widely known left-wing activist," in Onice's words, was in charge of introducing her to the Congregation of the Sisters Servants of the Immaculate Conception.

\footnotetext{
10 SILVA, Eni da. [Interviewed by] Caroline Jaques Cubas e Onice Sansonowicz. Itajaí, Sept. 2005. Author's collection.
} 
Onice, however, wanted to join the congregation, but in the municipality where she lived or, at least, nearby, in São Pedro do Sul, Rio Grande do Sul, Brazil, where the sisters servants' job refers only to entrance and not to education. Education, however, should take place in the communities of Medianeira, Paraná, ou Santa Maria, Rio Grande do Sul, where the congregation had school facilities. The big problem for Onice was the distance. After much insistence by Father Osvaldo, the sisters agreed to provide education in São Pedro do Sul, within the entrance period itself. Another issue, however, emerged. Onice was only 13 years old while, in the Congregation of the Sisters Servants of the Immaculate Conception's religious vocational education programs, since $1976^{11}$, a provision stated that it was not advisable to remove young individuals from their households before they reached 14 years of age and that, in these cases, monitoring should be carried out at home, through visits and letters.

"You want vocations, when we meet girls who want to devote themselves, mature, responsible girls, young, indeed, but those who have been engaged in pastoral work for a long time, you put up some obstacles!" These were Father Osvaldo's words, according to what was told to Onice, used to persuade the sisters to make an exception. In fact, days later, Onice's home was visited by some sisters willing to accept her in vocational education.

According to Grossi (1990, p. 52), religious vocations are "socially constructed by the Church's institutional representatives, along with the actual circumstances of families and communities." Thus, vocation is prompted by a set of factors that do not necessarily need to be religious or metaphysical. They concern social conditions, emotional ties, and personal and/or institutional projects.

Another requirement for joining the congregation, in addition to age, was the trousseau. For humble families, like Sister Eni's, that was as a big problem. She reports:

But she said, she gave me a list, that I should buy a trousseau. I had to have the trousseau, bring sheets, clothes, a certain number

\footnotetext{
11 Available in the collection of the Conference of Religious People of Brazil in Santa Catarina (Conferência dos Religiosos do Brasil - Santa Catarina [CRB-SC]). Fund "Reflection Group in Education" (Fundo "Grupo de Reflexão em Formação)".
} 
of blouses and skirts... and I... Where am I going to get money for all this? [telling about a dialogue with a friend]. Then I said, but regardless of that, I'm gonna tell the sisters that I'm going without trousseau, I have no money to buy it. And she said: no problem! I'm gonna cut my sheets. She took two double sheets, cut them in half and made four. So, she took a bath towel and another small bath towel, cut them and made two for the face. Then, when my sister saw that I was going, in fact, she also decided to buy some fabrics and made some skirts ${ }^{12}$.

Entering the congregation, therefore, did not depend only on appeal and will. As usual in various female congregations and orders since the colonial times, in Brazilian lands, and even before this, on European ground, one of the requirements for joining the congregation was the dowry. The dowry and trousseau, required just as in a marriage ceremony. Entry into the congregation was also a wedding. A marriage to the greatest fiance, according to the Christian religious tradition, symbolized by the use of a ring, and having vows as a basis. The profession and, hence, joining the congregation implied a series of commitments and choices. Choosing celibacy meant entering a new family. Before the Second Vatican Council, even the civil name was replaced by a religious name. The idea of family changed, consisting of new sisters during the religious vocational education process.

Religious vocational education is seen as the period in which the features, or the 'nun's character,' are under construction. Amadeu Cencini (2005, p. 222), in a course for educators, states: "educating, in turn, means having in mind a precise role model, a particular way of being that a person does not know, yet, and it must be progressively learned, in order to constitute her/his new identity." In this sense, religious vocational education in the Congregation of the Sisters Servants of the Immaculate Conception was (and it still is) divided into phases.

The first phase of religious vocational education was the aspirant group. It is stated in the congregation's guidelines that this moment should be "the time when, in a quest attitude, the applicant asks about her vocation to consecrated life and the Congregation assesses her skills"13. Thus, it was a duty of the sister in

\footnotetext{
12 SILVA, 2005, op. cit.

${ }^{13}$ CONGREGAÇÃO DAS IRMÃZINHAS DA IMACULADA CONCEIÇÃO - CIIC. Diretório. São Paulo: CIIC, [1982], p. 66.
} 
charge of vocational education to, carefully, observe the aspirant's behavior and help her to make decisions regarding religious life. The unfolding of this phase did not have a specific time. Its length was determined by the wishes and beliefs of the applicant and the sister providing education. At this time, the educator's work was direct and primordial.

To do that, when joining the aspirant group, the students received a small book entitled "Aspirant's handbook." The purpose of this handbook was to advise and monitor the issues related to this first stage, which, according to the handbook itself, was a moment of "looking for an identity." An identity to be embodied and taken throughout the training process. As the aspirant group usually coincided with teenage years, a stage when the prospective sister would still be at school age, it tended to take place near the congregation's school facilities.

The visible marks that characterize a sister in her maturity begin to be forged in this first stage. According to Grossi (1990, p. 52), "the aspirant group is regarded as an 'experience' period, where candidates for religious life must take into contact with the convent's daily life and assess whether they are interested or not in pursuing this career."

It was a quite complex transition moment, after all it represented quitting one's community and civilian family to enter the congregation. However, applicants would not be seen as de facto sisters, yet. They had not gone through the consecration rites. They just aspired to become sisters.

Some questions in need to be answered during this phase were: "Who am I? What do I want for my life? What are my skills? Why do I want to devote myself to the Lord in this congregation?"14.

Religious vocation emerges here as a seed, which needs attention and care. The latter could be taught through: study, work, leisure, prayer, fraternal life, pastoral engagement, reflections, reviews, meetings, readings, and courses. Particular emphasis was placed on the practice of prayer, whose overt function was to strengthen beliefs. Prayer was meticulously practiced throughout

\footnotetext{
${ }^{14}$ Manual da aspirante, used in the 1980s by Onice Sansonowicz. Onice Sansonowicz's collection.
} 
vocational education and this work started since the aspirant group. When recalling the significance of this practice, Onice shows a certain discomfort:

We got up at 6:30, I think... and prayed until 8:00 [...] That was torture for me, because they said at the retreats that if we didn't concentrate, we would be making way for the devil, if we felt sleep, that was devil's temptation, but sleep came... that was an inherent will of mine $e^{15}$.

More than a practice, prayer was demonstrated to students as a true art that should be learned (and) carefully and carefully trained. Through specific courses, using handouts and exercises, the girls were initiated in a practice whose sole and exclusive aim was "finding God in all things"16.

Initiation in such an art required - just as in any other, as pointed out by the booklet $A$ arte de orar [The art of praying], used in specific retreats on prayer - methods and willingness. In order to learn how to pray, a series of emotional and even physical attitudes were needed. Attention should be paid to deep breathing, absolute silence, and obstinacy. According to the booklet, one should "pray even when I'm not willing to do it or don't feel anything. [...] We pray as a comprehensive being, hence the importance of body position."

Religion, although regarded as a symbolic field, resorts to the body and is expressed in a bodily manner. Also, it serves to express religious attitudes such as worship, penance, petition, forgiveness, atonement, manifested by the body through noticiable looks, words, movements, and positions during the prayer practice (COMBLIN, 2005).

Prayer may be seen as an introspection exercise. An ascetic exercise. It requires self-discipline in face of the body and the mind. Self-discipline that, when not achieved, although disturbing Onice, was part of the teaching that, in religious life, the body needed to be tamed. Such practices refer to what Michel Foucault names as 'self-care,' which ranges from a practice to developing some knowledge that guides existence. It may be characterized as a set of tasks, and not as a general attitude. This is, in fact, a social practice, since it is also

\footnotetext{
15 SANSONOWICZ, 2006, op. cit.

${ }^{16}$ Booklet $A$ arte de orar. Onice Sansonowicz's collection.
} 
established in the relation to others. It consists of a series of concerns with the body; such concerns refer to physical ills that can communicate with the soul. Self-care is, therefore, the result of a series of procedures such as abstinence exercises, conscience assessment, night watch, and a series of practices concerning a self-control ethics.

The practice of prayer, in order to control the body and thoughts according to Christian assumptions, constitutes a governed, regulated behavior. Since the moment when praying means, just as the congregation's documents point out, "opening up to God and life itself," the latter plays a role in self-control as a theme. According to Kleber Prado Filho (2006, p. 28):

This new form of experience of a person in face of her/himself actually opens up to Christian subjectivation modes, implying reactive ways of self-control, focused on a ritual of deciphering an inner truth, which unfolds in a submissive relation. It is the birth of the Christian ethical experience.

Governing behaviors and self-discipline as an exercise through prayer were not exclusive to the aspirant group. They played a role at all stages of the training process and gradually marked the sisters so that they could be recognized throughout their lives.

To achieve these goals, the guidelines recommend an intensive effort in readings, conscience assessment, meditation, prayer of the rosary, penance exercises, liturgical celebrations, and, especially, participation in the daily mass and, if possible, confession, since, according to the guidelines, these practices provide the spirit with comfort to pursue the profession.

In the postulant group, the second phase of vocational education, concerns regarding the previous phase were resumed and they gained momentum. Also, it was hoped that at that moment there would be a rather serious study on religious vocation and an improved experience according to the congregation's assumption. At this stage, the student also began her biblical-liturgical-doctrinal studies, in addition to "developing her femininity in manual works, a lifestyle, in order to resemble Holy Mary"17, according to the congregation's guidelines. This

17 CONGREGAÇÃO DAS IRMÃZINHAS DA IMACULADA CONCEIÇÃO - CIIC. Diretório. São Paulo: CIIC, [1982]. 
model was an ideal pattern to be pursued by the sisters servants of the Immaculate Conception. Sister Maria Cristofolini, when asked about the main aim of belonging to the congregation, claims that it is "being holy."

Regarding the concept of holiness, André Vauchez highlights a certain amount of ambiguity, since the latter, while implying a human life's distinctive feature, also represents, in relation to the Divine, a possibility of purifying the reality which one tries to detach from. He refers to Rudolf Otto, who states that the "the saint's role consists in being both different and quite close to people; however, according to the times, it was more or less frequently seen in another pole of this definition" (VAUCHEZ, 1987, p. 287). After the Second Vatican Council, with the emergence of the idea of 'aggiornamento' along with Liberation Theology, new holiness parameters began to be outlined, according to which fidelity to the Church, the orthodoxy of its faith, and the model adopted before the believers become as appreciated as the requirement of proven miracles. Liberation Theology, according to Mairon Valério (2006), exacerbates these elements and foresees social love and political charity as a holiness foundation. The holiness foreseen by Liberation Theology is quite apparent in the words of Leonardo Boff (1981, p. 194), which I transcribe below:

\begin{abstract}
A saint is not only ascetic, a faithful man who observes the divine and ecclesiastical provisions, a person who has touched and embodied God's sacrosanct mystery, and his human appearance in Jesus Christ. All of this retains a perennial and never replaceable value. However, in grassroots communities, the situation opened room for another type of holiness, i.e. the militant. More than fighting against one's passions (this is an ongoing struggle), there is a political struggle, against spoliation and the generation of excluding accumulation mechanisms and in an effort to build rather community-based and balanced relationships.
\end{abstract}

These features, although the congregation as an institutional body did not officially engage in Liberation Theology, existed and they were, somehow, embodied, after all they are part of Sister Maria Cristofolini's memories. She claims that the holiness sought throughout religious life is not canonized holiness, but fidelity to Saint Pauline's example, being aware that these are real and true people dealing with real and true people, with their issues and constraints. It is clear that, even appreciating these new predicates and models to the detriment 
of others, recognizing the features of holiness surely remains dependent on the Catholic Church's official endorsement.

The characteristics that constitute this holiness are those professed later in the ceremony of perpetual vows. Even before the rite, which took place only in the novitiate, the third vocational education phase, the vows already began to be experienced, somehow.

Obedience, chastity, and poverty are everyday nouns in the students' lives. Sister Eni vividly recalls the difficulties existing in the vocational education houses particularly regarding community life. The latter implied the exercise of attitudes that, in the future, might shape the vows and represent the effective entry into a life institutionally devoted to religion. She recalls that the adoption of community life did not always happen in a festive way. She narrates a passage of her training years, repeating the words of the sister in charge of her vocational education:

Look, I'm gonna held a meeting and let's decide if you want to have everything in common. Let's do this experiment. Whoever wants to have everything in common, if you agree, we will do it. If you want to share, it is... each one has things of her own, too. Then I thought: oh, my God, if everything is shared it will be great for me, because I will surely have what I don't have now and I will offer the few things I have... I will share everything. But there were some people who had more money and they said: we don't want this. One of them: I don't want this! She had a lot of money... but she was the only one who reacted this way. OK, but what about those who brought less? Some people brought more and others brought less... What about it? So, the sister said [...]: those who have a lot give a lot, because they will always receive something, too. And those who have a little receive, but give a little, but that is a lot for her, because it is everything she has ${ }^{18}$.

Community life, however, was not the only standard that had to be learned. Another one, equally complex and in needed to be embodied over the years, concerned the education of feelings. In this regard, Sister Cristofolini explains that feelings existed because life was communal (along with the other), so there was a need to educate feelings. Such an education took place through retreats and studies on self-awareness and otherness. It often refers to self-assessment

\footnotetext{
18 CRISTOFOLINI, Maria. [Interviewed by] Caroline Jaques Cubas. Florianópolis, Jan 31st. $2006 a$. Author's collection.
} 
(through psychoanalysis), used to find out the cause of certain feelings, whether they were good or bad. The other is known through self-awareness and this happens by means of psychology, prayer, and reasoning ${ }^{19}$. Once again, the exercise of ascetic practices was related to issues concerning what we know as self-care. According to Foucault (2007, p. 72), when referring to a sexual morality:

[...] of abstinence and dominance that constitute the askesis needed, the place assigned to self-awareness becomes more important: the task of putting oneself to the test, assessing oneself, controlling oneself in a series of well-defined exercises, poses the issue of truth - a truth about who a person is, what she/he does, and what she/he can do - at the heart of the moral individual's constitution.

Such practices served the purpose of controlling bodies, since sexuality might be a desecration of the sacred body. However, there were some ways to circumvent such control and they are reported by Onice when she claims that the most important thing is not feeling something (in terms of sexuality), but what is done in face of this feeling:

We talked a little bit... I remember that I was on fire... [laughs]. I studied with great colleagues... The goal was praying... [laughs]. But we talked... Nothing ever happened... Not even a kiss, but our bodies... We were always hugging each other [like the priests] and hid what we felt... We enjoyed sensuality and eroticism... ${ }^{20}$.

We may address Onice's description in the light of tactics discussed by Michel de Certeau in this movement of inventing and reinventing everyday life. In this case, the erotic experience in a very moralizing atmosphere could constitute a tactic, a way to escape from disciplinary and moralizing control, since this way may be regarded as a "non-place (which) undoubtedly provides it with mobility, but in a docile manner in face of the misfortunes of a time, in order to capture in flight the possibilities offered for an instant” (CERTEAU, 1994, p. 100).

The existence of such tactics, however, does not deny the certainties needed in relation to vows in the last vocational education stage, the novitiate. This phase consists of an intensification of what had been previously studied, in

\footnotetext{
19 Ibidem.

20 SANSONOWICZ, 2006, op. cit.
} 
addition to encompassing the study of of Jesus Christ as a person and how his message was experienced; doctrinal and biblical education; documents belonging to the Church; a catechesis course divided into stages (baptism, confirmation, eucharist); liturgy - mariology; religious life theology; study of constitutions in the original formulation of founders and in their current dynamism; human-social education; primary health principles; study and analysis of reality.

This stage lasted for 2 years and it could be extended for 6 months. It was from this point on that the first profession emerged in vocational education, the renewal of vows, the perpetual profession of juniorate, i.e. a period of community experience and deepening of what had been seen throughout vocational education, after the vows.

To do this, there were very specific criteria in the congregation's guidelines: zeal to comply with the congregation's constitutions, guidelines, and standards; interest in the community, province, congregation, and Church; living the congregation's spirit; community integration; open and straightforward communication; ability to pursue a profession within the congregation; ability to love and forgive; respect for oneself and the others; courage - spirit of sacrifice; common sense; critical sense; detachment from people, places, and things; coresponsibility/maturity; escape from conditioning; self-control; physical and mental health; love for the poor and the population; apostolic and missionary zeal.

The ceremony of vows was quite simple, preceded by a retreat that lasted about 8 days. It was, as Bourdieu (1998, p. 167) points out, an institutional rite that may legitimize the choice of a person who had decided for experiencing religion on an institutional basis before the congregation members and the group of believers, after all, the effectiveness of this rite is put into practice only "insofar as the target individual acknowledges that the person who is in charge of it is actually legitimized to do this." Starting from this rite, the novice will finally be acknowledged as a sister. Such a rite represents the commitment to the congregation and to God, symbolized by the ring that she starts using from then on. 
Because religious women belong to the religious field, they also become bearers of a series of symbolic goods related to their specific field. In their case, the recognition that they possess such goods depends on their vocational education process ${ }^{21}$. In this process, consisting of various phases, in which people learn to pursue a religious life, habits and customs are embodied. Paraphrasing Miriam Pillar Grossi, the 'nun's character' is learned. Perpetual vows (chastity, obedience, and poverty) took place in a ceremony that finally acknowledged that a woman pursued a religious life. It is the institution rite through which a religious woman was acknowledged as possessing the salvation requirements.

The authorization to speak on behalf of the institution, however, would be relativized. A religious sister is linked to the ecclesiastical institution by her vows; she is recognized by lay people as a religious person undergoing a differential process. Sacred life and its specific habitus (understood as the naturalization of features and the incorporation of social rules) will, generally, distinguish religious and lay people 22 . However, a sister does not participate in the ecclesiastical hierarchy, something which clearly hinders her possibilities of speaking on behalf of the institution. It is worth remembering that, even making perpetual vows, a sister is not ordained as a priest and, therefore, she cannot celebrate the sacraments. She does not participate in synods and the most significant definitions within the Church. Her working settings, on behalf of the same institution, which vehemently restrict her participation, are limited to pastoral activities in grassroots communities, schools, hospitals, etc.

In the early $20^{\text {th }}$ century, women were even prevented from participating in corals. This prohibition extended until 1940, when Pius XII allowed women to sing, as long as they remained outside the presbytery and the communion table. The Code of Canon Law, in force since 1983, states, in canon 230, that the office

\footnotetext{
${ }^{21}$ When explaining the genesis of the religious field, Bourdieu resorts to Max Weber and highlights distinctions between the priest's place, who would undergo a vocational education process to speak on behalf of an institution, and the prophet, who would possess the goods even without recognizing this process and lacking links to any institution.

22 I say generally because this distinctive process poses some complexities that will not be discussed here, but that deserve to be highlighted, especially after the Second Vatican Council and the attempt to delimit new forms and meanings for religious life.

In this sense cf. CUBAS, Caroline J. Rompendo hábitos: significados do uso do hábito e do seu abandono pelas Irmãzinhas da Imaculada Conceição. In: SIMPÓSIO MUITAS FACES DO CRISTIANISMO, [n. d.], 2005, São Paulo. Anais [...].São Paulo: CEHILA, 2005.
} 
of acolyte, the liturgical ministry, can be exercised only by men ${ }^{23}$. Also in the early 1980s, Pope John Paul II came to prohibit the participation of women even in the roles of assistants for masses. This decision was revoked in 1994. Also in 1994, exactly on May 22, the same pope ratified the impossibility of female priesthood, using, as an argumentative support, the 1975 Paul Vl's statements and the Bible. Female non-ordination was definitively denied.

Despite vehemently denying the possibility of female ordination, the Pope assigned, in the apostolic letter Ordinatio Sacerdotalis, a key importance to women's role in the life and mission of the Church, providing them with the responsibility of "renewing and humanizing society, as well as rediscovering, among the believers, the true face of the Church"24. Religious women, sisters, are given the role of spreading the Church's truths among believers. Truths that should be learned over the lengthy vocational education process. Truths that religious women, when working in a social environment, could teach through work and example. Truths in face of which they, the sisters, have no power to define.

\footnotetext{
${ }^{23}$ Cf. IGREJA CATÓLICA APOSTÓLICA ROMANA. Código de Direito Canônico. Cidade do Vaticano: Concílio Vaticano II, 1983.

24 JOÃO PAULO II. Ordinatio Sacerdotalis (22 de maio de 1994). Cidade do Vaticano: Concílio Vaticano II, 1983.
} 


\section{References}

BOFF, Leonardo. Igreja: carisma e poder. Petrópolis, RJ: Vozes, 1981.

BOURDIEU, Pierre. Economia das trocas linguísticas. São Paulo: Edusp, 1998.

CENCINI, Amadeu. Proposta de um itinerário pedagógico do jovem consagrado. Curso para formadores. Roma, 26 a 28 de junho de 1998. In: PEREIRA, Willian (org.). Análise institucional da vida religiosa consagrada. Belo Horizonte: CRB, 2005. p. 221-238.

CERTEAU, Michel de. A invenção do cotidiano. Petrópolis, RJ: Vozes, 1994.

COMBLIN, José. Cristianismo e corporeidade. In: SOCIEDADE DE TEOLOGIA E CIÊNCIAS DA RELIGIÃO - SOTER (org.). Corporeidade e teologia. São Paulo: Paulinas, 2005. p. 7-20.

CONGREGAÇÃO DAS IRMÃZINHAS DA IMACULADA CONCEIÇÃO - CIIC. Diretório. São Paulo: CIIC, [1982].

CONGREGAÇÃO PARA A CAUSA DOS SANTOS. Madre Paulina: fundadora da Congregação das Irmãzinhas da Imaculada Conceição - biografia comentada. São Paulo: [s. n.], 1986.

CUBAS, Caroline J. Rompendo hábitos: significados do uso do hábito e do seu abandono pelas Irmãzinhas da Imaculada Conceição. In: SIMPÓSIO MUITAS FACES DO CRISTIANISMO, [n. d.], 2005, São Paulo. Anais [...].São Paulo: CEHILA, 2005.

FOUCAULT, Michel. Vigiar e punir: história das violências nas prisões. Petrópolis, RJ: Vozes, 1998.

FOUCAULT, Michel. Historia da sexualidade: o cuidado de si. São Paulo: Graal, 2007. v. 3.

GROSSI, Miriam Pillar. Jeito de freira: estudo antropológico sobre a vocação religiosa feminina. Cadernos de Pesquisa, São Paulo, n. 73, p. 48-58, 1990.

IGREJA CATÓLICA APOSTÓLICA ROMANA. Código de Direito Canônico. Cidade do Vaticano: Concílio Vaticano II, 1983.

JOÃO PAULO II. Ordinatio Sacerdotalis (22 de maio de 1994). Cidade do Vaticano: Concílio Vaticano II, 1983.

PRADO FILHO, Kleber. Michel Foucault: uma história da governamentalidade. Rio de Janeiro: Achiamé, 2006. 
VALÉRIO, Mairon Escorsi. Mártires do reino: o conceito de santidade na teologia da libertação. In: SIMPÓSIO INTERNACIONAL SOBRE RELIGIÕES,

RELIGIOSIDADES E CULTURAS, 2., 2006, Dourados. Anais [...]. Dourados, MS:

UFMS/UFGD, 2006.

VAUCHEZ, André. Santidade. In: ROMANO, R. (Dir.). Enciclopédia Einaudi. Lisboa: Imprensa Nacional/Casa da Moeda, 1987. v. 12, p. 287-300.

\section{Correspondences}

SANSONOWICZ, Onice. [Correspondence]. Addressee: Irmã Eni. 2005. 1 personal letter.

\section{Interviews}

BOLZAN, Leodi. [Interviewed by] Caroline Jaques Cubas. Itajaí, Sept. 2004. Author's collection.

CRISTOFOLINI, Maria. [Interviewed by] Caroline Jaques Cubas. Florianópolis, Jan 31st. 2006a. Author's collection.

CRISTOFOLINI, Maria. [Interviewed by] Caroline Jaques Cubas. Feb 7th. 2006b. Author's collection.

SANSONOWICZ, Onice. [Interviewed by Caroline Jaques Cubas. Mar 26th. 2006. Author's collection.

SILVA, Eni da. [Interviewed by] Caroline Jaques Cubas e Onice Sansonowicz. Itajaí, Sept. 2005. Author's collection.

Universidade do Estado de Santa Catarina - UDESC

Programa de Pós-Graduação em História - PPGH

Revista Tempo e Argumento

Volume 12 - Número 29 - Ano 2020

tempoeargumento@gmail.com 